\title{
Homeopathy: synopsis
}

\section{Origins}

The German doctor Christian Friedrich Samuel Hahnemann published the homeopathic proposals for the first time in "Organon der Heilkunst", in 1810. They were extended later in six volumes of "Pure Medical Matter" between 1820 and 1827. At Hahnemann's time the fact that all living beings are formed by cells was not fully established. Even though M. Malpighi had confirmed the presence of cells in vegetal tissues in 1675 using the microscope, and A. van Leeuwenhoek had described cells and its nucleus in 1719, the definitive cellular theory of living organisms was postulated for plants and animals only in 1838 and 1839, respectively, by M.J. Schleiden and T. Schwann. Hence, at Hahnemann's time the complex biochemical, physiological, and functional relations of the different organs in the human body at cell level remained unknown. Modern biochemistry, as recognized today, began with the synthesis of urea in 1828 by F. Wöhler, when he proved that organic compounds could also be synthesized out of the living beings, contrary to the generalized believe that these compounds could only be formed inside of them.

When Hahnemann published his books, surgeries were carried out without anesthesia (Crawford, 1842), it was not known that microbes were the cause of many illnesses (Pasteur and Koch, 1870) and the role of vitamins in the organism was ignored (Gowland, 1906). Penicillin and antibiotics were unknown (Fleming, 1929); as well as X-rays, radioactivity and genetics, and the present criteria about ethics, clinical trials, biasing, the Evidence-based Medicine and the Cochrane collaboration were not established. ${ }^{1}$

\section{Contemporary homeopathy}

Up today, contemporary homeopaths preserve Hahnemann's
Volume 8 Issue 2 - 2019

\author{
A González Arias \\ Havana University, Cuba
}

Correspondence: A González, Havana University, Cuba,Tel 72057984,Email Ariasarnaldo@fisica.uh.cu

Received: March 01, 2019 | Published: April 29, 2019

proposals without change, although the homeopathic postulates have nothing to do with the development of physics, chemistry, biology, medical, and any other science in the last 200 years. It has been pointed out that if a doctor of the XIX ${ }^{\text {th }}$ century would come to the present day, would have to renew all its knowledge. If a homeopath of the $\mathrm{XIX}^{\text {th }}$ century would come to the present day, would not have to renew anything. ${ }^{2}$

\section{Preparation and display of the product}

The homeopathic products form by means of a series of successive dilutions and a manual agitation of the receptacle after every dilution, many times up to a point in which there does not remain practically nothing of the original substance (mother dye) in the final product. They display in similar form to conventional medicines, but usually without specific indications about its form of preparation or real content of the allegedly 'active' product (see figure). The usual form of consumption is putting several drops under the tongue. A variant is to add a drop of the final dissolution to a sugar pellet as in Figure 1, to swallow it as a pill. ${ }^{3}$
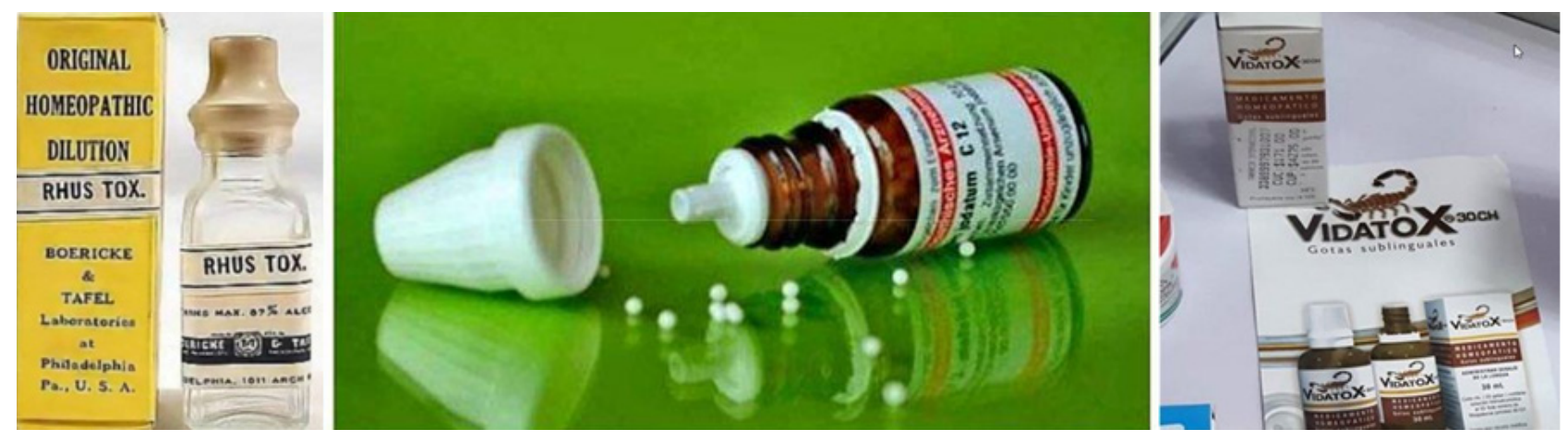

Figure I Homeopathic products.

\section{A paradise for opportunistic}

The preparation features of the homeopathic products build paradisiac conditions for all kinds of opportunisc people. In most cases (concentrations $12 \mathrm{CH}$ and higher, allegedly the more potent by homeopaths) there is no way of differentiating a homeopathic product of a simple mixture of mineral water and flavoring, as well in its liquid form or as mixed with sugar. Since in both cases the original substance is practically absent of the final product, it is impossible to demonstrate before a court the attempt of swindle by means of chemical analysis, or any other technique. The consumer has no more option that to trust blindly in the one who gives him the product, which in many places sells without supervision of any state agency that guarantees its authenticity (as it happens, on the contrary, with conventional medicines or foods, which most times are subject to strict sanitary regulations). 


\section{Clinical trials}

The most recent clinical trials (metaanalysis Cochrane) on homeopathy, ${ }^{4}$ designed to avoid tendentious (biased) results and based on modern criteria about the ethics, the real benefit to the patients and the clear differentiation of the placebo effect, ${ }^{5}$ do not show real benefits of the homeopathy in any condition beyond the placebo. ${ }^{6}$

\section{Acknowledgments}

None.

\section{Conflicts of interest}

The autor declares that there is no conflicts of interest.

\section{References}

1. https://www.google.com/search?client=firefox-b-d\&q=History+of + Medi cine+in+wikipedia.com

2. http://www.geocities.ws/rationalis/homeo-una-ilusion/RCF-25012008-p38.pdf

3. Ana Portilla Ferreira, Ana Granados. La homeopatía suspende matemáticas. Regresar a rationalis. 2018.

4. http://www.geocities.ws/rationalis/2019/resumen-clinico/index.htm

5. http://www.geocities.ws/etica-placebo/bueno-malo-feo/index.htm

6. Homeopatía. Regresar a Rationalis. 2018. 